\title{
ANALYSIS OF COASTAL WOMEN EMPOWERMENT MODELS IN TAKALAR REGENCY
}

\author{
Nuraeni Kadir ${ }^{1}$, Abdul Razak Munir ${ }^{2}$, Wahda $^{3}$
}

\begin{abstract}
Community empowerment of fishermen should be bottom up and open the menu. However, the most important is the empowerment itself must directly touch the target community. The objective of this research is to analyze the empowerment model of coastal women in the form of aspirations, knowledge, skills, and perception in increasing the income of seaweed cultivation in Takalar Regency, and to analyze the driving factors and government policy in empowering coastal women to increase seaweed farming income in Takalar District. This study uses an inferential cross-section design to assess the interrelationship between variables. The sample in this research is coastal women in Takalar District, which amounted to 210 respondents. The research instruments include questionnaires, observation sheets and Focus Group Discussion (FGD). Data analysis was done descriptively quantitative by using frequency statistic technique and percentage. The involvement of family members in coastal community households such as wives and children in livelihood activities has become a model of adapted livelihood adaptation strategies both traditionally and as a result of the dynamics of the social and economic environment. Thus, the condition of households of coastal communities or the role of women who have been contextualized in such a way as to increase the family's economic income.
\end{abstract}

Keywords: Empowerment Model, Coastal Woman, Empowerment Factor and Income

\section{Introduction}

Community empowerment is a process of development in which the community is an initiative to initiate the process of social activities to improve the situation and conditions themselves. Robinson (2010) explains that empowerment is a personal and social process; a liberation of personal ability, competence, creativity and freedom of action while Simon (1993) illustrates that empowerment is an act of reflection, a process that can be initiated and maintained only by agents or subjects who seek strength or self-determination.

As an integral part of national development, community empowerment gains enormous attention and as part of the form of national policy. Through the fuel subsidy reduction compensation program, it launched a productive economic funding aid for several fields managed by related departments. Ministry of Marine and Fisheries Affairs, one form of 
compensation program through the launching of productive economic funds is packaged in the form of Community Empowerment Program (PEMP) which began in 2001. According to Kartasasmita (1996), community empowerment is a concept of economic development that encapsulates social values. The purpose of coastal community empowerment is the realization of the economic structure of Indonesia based on economic activities in coastal and marine areas as a form of utilization marine natural resources.

The involvement of family members in coastal community households such as wives and children in livelihood activities has become a model of adapted livelihood adaptation strategies both traditionally and as a result of the dynamics of the social and economic environment. Thus, the condition of coastal community responses or the role of women who have been participated in such a way as to increase the family's economic income.

It becomes a problem in almost every coastal region of Indonesia that people who live in the coastal area have low income compared with people living in urban areas. In line with that, Dahuri (2001) explains the image of poverty of coastal communities is actually an irony, considering Indonesia has a wide sea area. In fact, there are a lot of resources that have high economic potential that should be utilized to ensure the welfare of coastal communities and their families. Coastal communities, consisting of fishermen, fish product processed specialist, traders, and other works where their life depends on marine resources, is a worker segment that is generally still in low-income segment. The welfare of coastal communities requires new breakthrough programs that can improve access to capital, management, and technology and can transform the structure and culture of coastal communities.

According to Sumantri (2008), the factors of coastal community empowerment that need to be considered and actualized are the supporting factors and government policy factors. Macro supporting factors such as a society have their own characteristics that are influenced by the geographical, demographic, social, and cultural conditions of a community in conducting the empowerment program. Micro and specific supportive factors for empowerment activities are government policies that focus on empowerment of potentials in accordance with the field of interest so that government policies must be able to provide or establish adequate infrastructure, establish pricing policies and determine the marketing mechanisms of products.

In seaweed cottonii or spinosum cultivation, the division of labor within the coastal community (men and women) has been equally distributed to all core members, whether children, adults or parents, men, and women all involved in business activities with different roles and portions. Stereotype model construction illustrates that for the preparation of land, 
maintenance and harvest are done by men, while the involvement of women in terms of making rope, battle rope, seedling, and seaweed drying.

One of the phenomena occurring in the coastal area of Takalar Regency is the empowerment of the community, in this case, the empowerment of coastal women that can not be separated from the government activities in conducting community empowerment through the National Program of Independent Community Empowerment in the Marine and Fisheries sector (PNPM Mandiri KP). The target of this program is marine and fishery coastal communities incorporated in business groups including seaweed cultivation business. The existence of the program is expected to improve the welfare of the community in the area, therefore the implementation of the program should be fully evaluated as one of the efforts to improve and develop the management so that the objectives of the program can be fully felt by the coastal women. But the fact is that the program has not been fully able to increase the income of coastal women. In connection with the above, we raised the problem in the form of research with the title: Analysis of Coastal Women Empowerment Model in Increasing Seaweed Revenue in Takalar Regency.

\section{Methodology}

\section{Type and Object Research}

This research is a survey research conducted through the analysis of questionnaires from respondents. The object of study is a coastal woman who works in seaweed cultivation in Takalar Regency.

\section{Population and Sample}

The population in this research is seaweed culture woman in Takalar regency which amounted to 210 people. Sample determination using a total sample or a saturated sample, in which the entire study population was sampled. So the sample size in this research is 210 respondents.

\section{Discussion}

Based on the research result, it can be shown the model of coastal women empowerment that can be applied in increasing the income of seaweed farming in Takalar Regency. 


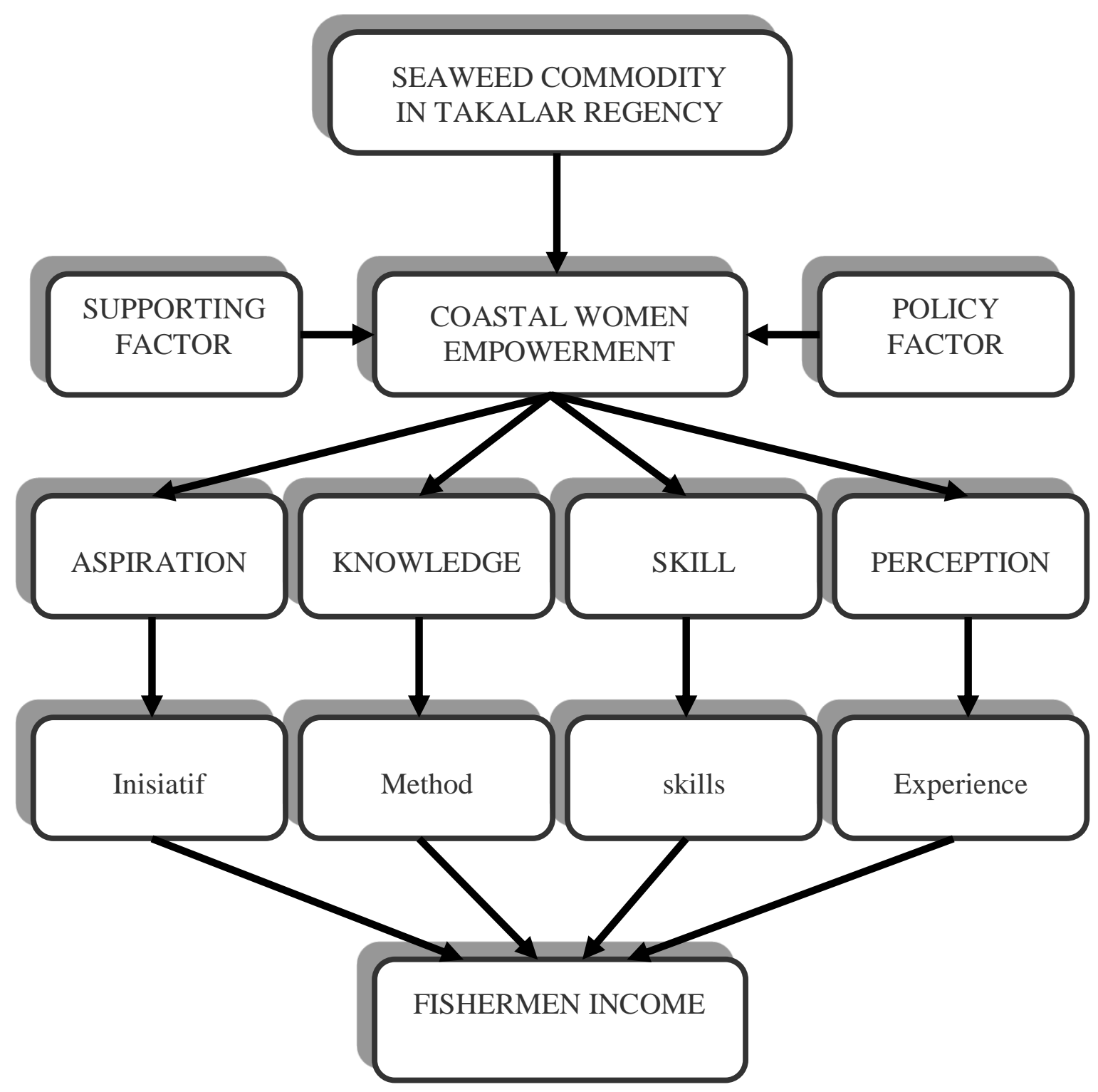

Picture 1

Empowerment Models of Coastal Seaweed Cultivation Women 
Based on the results of research on the analysis of empowerment model of coastal women in Takalar regency, indicate that the need to apply the right model to empower the coastal women who do seaweed cultivation, so that the income increases.

The people-centered development model and the development object sees the initiative and creativity of the people as the main source of development and views the welfare of society as the goal to be achieved in the development process. Sanrobone District is an integral part of development programs and policies in Takalar. Various development programs and community empowerment conducted either through national or regional policies seeks to make the community empowered, thus increasing the income of the community. One of the problems is how to increase people's incomes through empowerment when empowerment programs have been implemented but do not have a significant impact on income generation, especially coastal communities.

Community income as a form of cash flow flowing from the business community to the community in the form of loan capital of the collecting party and the wage of seaweed crops. Personal income in the form of harvest wages sold to collectors. Community welfare is the goal of economic development in accordance with the income of each family. Sitorus (1994) states that the living standards of coastal villagers, mostly fishermen, are still low. Income is uncertain (highly dependent on the fish season), most still using traditional equipment and it is still difficult to distance them from extravagant behavior.

In line with the above opinion in order to achieve a prosperous society, it needs a sustainable empowerment model that is essentially oriented towards improving human prosperity and welfare by involving all development process, besides that development should aim at realizing the welfare of society. The empowerment model is part of a development paradigm that focuses its attention on all the principal aspects of human beings in their environment, ranging from the intellectual (human resources) aspects, material and physical aspects, to the managerial aspect. These aspects may be developed into sociocultural, economic, political, security and environmental aspects. Community empowerment is a concept of economic development that encapsulates social values, the concept reflects the new paradigm of development, which are people-centered, participatory, empowering, and sustainable. Efforts to empower people can be seen from three sides namely:

1. Creating a condition that enables the potential of the developing community (enabling). Here the starting point is the recognition that every human being, every society, has the potential to be developed. That is, there is no society at all without 
power because then it will be extinct. Empowerment is an effort to build that power, by encouraging, motivating, and awakening awareness of the potential it has and working to develop it.

2. Strengthen the potential or power possessed by the community (empowering). In this framework required more positive steps, apart from just creating a climate and atmosphere. This reinforcement includes concrete steps and involves the provision of inputs, as well as opening access to opportunities that will make people more empowered.

3. In the context of this empowerment, the most important effort is to improve the level of education and health degree, as well as access to sources of economic progress, such as; capital, technology, information, employment, and markets. It needs to be a special program for people who are less empowered, because the general programs that apply to all, cannot always touch this layer of society.

Sanrobone District is one of the sub-districts within Takalar District government. Sanrobone District with an area of $29.36 \mathrm{~km} 2$ with a percentage of $5.18 \%$, with 6 villages and 31 hamlets have the potential of seaweed cultivation commodities, inhabited by 13,766 residents consisting of 6,474 male and 7,292 female.

Population in Sanrobone sub-district is dominated by population with the education level of Diploma and Bachelor (515 people) and High School (446 people). They are mainly farmers which rest are a laborer, trader, handyman, farmer, and others. The social condition of the community which in terms of religious beliefs is dominated by Islam supported by the availability of public facilities such as schooling, village offices (including village meeting halls), health care center and sports facilities.

Community income is closely related to economic activities, fisheries and other businesses undertaken by the community in supporting daily income. Efforts to increase people's income through empowerment programs include:

1. Business capital loan assistance through a national program of rural community empowerment.

2. Development of motivation to work and strive through training and counseling.

3. Economic business skills training.

Loan business capital assistance related to soft loans and revolving funds intended for business activities both in developing the business and the opening of new business from coastal seaweed commodities communities. The development of motivation to work and try 
through training and counseling is the activity undertaken by the government to encourage and improve the business community. It is expected to manage the seaweed cultivation to run well so the income of the coastal community increases. Increased motivation is seen from the increase in the spirit of running the work/seaweed business as well as by utilizing the resources and potentials and facilities owned, increased enthusiasm to obtain maximum business results from work or business while the spirit or desire to develop business activities and work is being done in seaweed production.

Furthermore, skill training activities are related to training programs undertaken to develop and improve businesses that lead to increased incomes of coastal communities. The training program has made the community knowledge and skills in the business field, the existence of the ability to manage and run the business and increase the ability to overcome various problems faced in running the existing business.

Low or high-income farmer is depending on how much their needs especially for daily basis. Some respondent said that soft loans from non-government are really helpful to support and develop their business. However, they admitted that the fulfillment of the needs of both clothing and food also cannot be avoided. Somehow, they use the profit of his business to finance the needs of the family in terms of fulfillment of consumption.

The concept of community empowerment as the theory of Kartasasmita (1996: 159160) which suggests three dimensions that affect the empowerment of society (1) enabling the creation of a climate that is able to encourage the development of community potential, (2) empowering the potential that is owned by the community is more reinforced and (3) protecting the potential of the weak community in all things need a balanced protection for the competition that is running in a healthy way.

In the program of financial assistance, the provision of business motivation and business training activities brings a tendency to community empowerment that emphasizes the process of stimulating, encouraging or motivating individuals to have the ability or empowerment to determine what their life choices are. The enabling dimension is an effort to create an atmosphere or climate that enables the potential of the developing community Here the starting point is the recognition that every human being, every society, has the potential to be developed. Empowerment is an effort to build that power by encouraging, motivating, and awakening awareness of their the potential and trying to develop it. 
In community empowerment through financial assistance to coastal communities will be largely determined by the climate created by the government that acts as the spearhead of the community financial aid program. Community empowerment in the form of hard-working encouragement is an effort to spur the spirit in each person to be able to do something more. Creating an atmosphere or climate that enables the potential of the developing community begins with the community to work harder. Hard work will lead to increased productivity (results) work. In addition, there is also a strong desire from within each member of the village community to be more advanced.

Giving motivation is an effort to encourage a person's spirit with incentives or something help. It could meet the daily needs, also be a gift of money or goods incentives to increase the passion of work. Motivation also contains hope, in the form of desire at some time later obtain a decent and better livelihood. Motivating is an attempt to trigger a person or group of people to perform an action or increase the intensity of the ability. Dimensions of empowering are to strengthen the potential or power possessed by the community (empowering). In this framework, more positive steps are needed than just creating an atmosphere. This reinforcement involves concrete steps and involves the provision of inputs, as well as opening access to opportunities that will make people more empowered.

Empowering is to provide additional power or capability, in general, coastal communities have limited power and capabilities but have not yet appeared optimally in the use and achievement of results. In other words, people are able to walk slowly but not able to walk fast, with empowering expected to be able to independently run fast in various activities of their activities. In empowering it takes more positive steps besides just creating a good climate and atmosphere. This reinforcement includes concrete steps in the provision of inputs and access to opportunities that will make communities more empowered. For that, there needs to be a special program for people who are less empowered because the general programs that apply to all cannot always touch this layer of society.

The program of financial assistance, training and motivation are expected to become independent in managing and developing business so that the income of the society is increasing, fulfillment of the necessity of the business life of semanin increase. Increased revenue in terms of seaweed business requires the support of all parties including the availability of facilities and infrastructure. 
Increased public revenues are part of the implementation of development and even distribution of the results to all public spaces without exception including community economic development. The empowerment of coastal communities among others revolves around how to strive for the community can become the main actors in economic development and can utilize resources optimally and responsibly. Non-fiscal financial aid program cannot be directly seen the results because it requires a long process of behavior, attitude, and culture of the community. It can start from the introduction stage, socialization, giving examples, training, counseling, and field practice. But what is certain is that people start and have the will, strength and capacity to utilize the potential they have. Community empowerment becomes meaningful for the increase of income, among others, about how to make the society become the main actors in economic development and can utilize the resources optimally and responsibly with the community start and have the willingness, strength, and ability to utilize their potential.

Based on this matter needed a right model in doing community empowerment in this case coastal women in increasing their income from seaweed cultivation in Takalar regency. The model is a model of empowerment of coastal women. The model was developed in view of the role of coastal women in helping family income play an important role, especially helping the husband's income as a fisherman and fulfilling family needs such as fulfilling household consumption and tuition fees.

For the role of women in seaweed cultivation, it has been utilized and used for collecting traders to utilize the business capital given in managing the potential of seaweed in the surrounding environment. Women's involvement in this case wives and daughters have been empowered in conducting seaweed cultivation, in general women in Takalar District, especially in Sanrobone Sub-district, have been empowered to increase their aspirations in generating initiatives to supplement income. Has been empowered by increasing knowledge with various methods or ways of conducting a cultivation that has high quality selling value to supplement income. Empowerment has been done by improving skills according to skill in conducting seaweed cultivation to increase their income. Have empowered their perception of seaweed cultivation that is occupied as an important experience to increase its income. Women's empowerment efforts undertaken so far have benefited the increased income of fishermen families so that these empowerment activities or programs are accepted by the community. And this is not apart from the supporting factors in the form of topography, demography, social and cultural community and supported by government policy factors such as rules and government participation in the development of seaweed cultivation business. 


\section{Conclusion}

1. Based on the results of research and discussion, it is concluded as follows: Models of coastal women empowerment in the form of aspirations, knowledge, skills, and perceptions have been applied in increasing the income of seaweed farming in Takalar Regency. The involvement of coastal women in conducting seaweed cultivation activities is empowered to increase the aspirations that give birth to initiatives to increase income, increase knowledge with various methods or ways of conducting cultivation that has high quality selling value to increase income, have skill according to skill in conducting seaweed cultivation to increase its income, and perception of seaweed cultivation that is occupied as an important experience to increase its income.

2. There are a driving factor and government policy in empowering coastal women to increase seaweed farming income in Takalar District. Supporting factors are topography, demography, social and culture of society, while government policy factors such as rules and participation of government parties that can provide convenience for coastal women in the development of seaweed cultivation business.

\section{References}

Dahuri, M. 2001. Mencermati Misteri Globalisasi: Menata Ulang Strategi Pemberdayaan Masyarakat Indonesia Melalui Pendekatan Resource-Based. Depok: Fisip Universitas Indonesia.

Jamasy, O. 2004. Keadilan, Pemberdayaan, \& Penanggulangan Kemiskinan. Jakarta Selatan: Blantika.

Kartasasmita, G. 1996. Power and Empowermant: Sebuah Telaah Mengenal Konsep Pemberdayaan Masyarakat. Jakarta: Badan Perencanaan Pembangunan Nasional.

Kusnadi, E. 2002. Pendidikan dan Pertumbuhan Ekonomi. (Article on-line). Didapat dari http://www-theindone-sian-institute. org/ janeducfile.htm. Internet.

Pranarka dan Vidhyandika, 1996. Pemberdayaan dalam Onny S.P dan AMW. Pranarka (ed). 1996. Pemberdayaan: Konsep, Kebijakan dan Implementasi. Jakarta: Center for Strategic and International Studies (CSIS).

Romer, P.M. 2010. Endogenous Technological Change. Journal of Political EconomyVol. 98, No. 5, Part 2: The Problem of Development: A Conference of the Institute for the Study of Free Enterprise Systems (Oct., 1990), pp. S71-S102. The University of Chicago Press, http://www.jstor.org/stable/2937632 
Simon, H. 1993. Pemberdayaan Masyarakat Pesisir. Problematika dan Strategi Pemecahannya. Yogyakarta: Aditya Media.

Soeharjom, dan Patong, 1994. Pemberdayaan Masyarakat. dalam Membetuk Pola Perilaku Manusia Pembangunan. Disunting oleh Ida Yustina dan Adjat Sudradjat. Bogor: IPB Press.

Sumantri, 2008. Analisis Jaringan Sosial: Menerapkan Metode Asessmen Cepat dan Partisipatif (MACPA) Pada Lembaga Sosial Lokal di Subang, Jawa Barat: http://www.policy.hu/ suharto/ mak-Indo4.html. Diakses pada 28 Juli 2005.

Sulistiyani, A.T. 2004. Kemitraan dan Model-Model Pemberdayaan. Yogyakarta: Gaya Media.

Sumardjo. 1999. Transformasi Model Penyuluhan Pertanian Menuju Pengembangan Kemandirian Petani: Kasus di Propinsi Jawa Barat. Disertasi Doktor. Bogor: Program Pascasarjana Institut Pertanian Bogor.

Sumodiningrat, G. 2000. Visi dan Misi Pembangunan Pertanian Berbasis Pemberdayaan. Yogyakarta: IDEA.

Sastrawidjaya, R. 2002. Modal Sosial: Konsep dan aplikasi. Jurnal Masyarakat dan Budaya. Vol.V. N0.1:1-5.

Tito Sumarsono, M. 2011. Pembangunan Dilema dan Tantangan. Yogyakarta: Pustaka Pelajar. 